
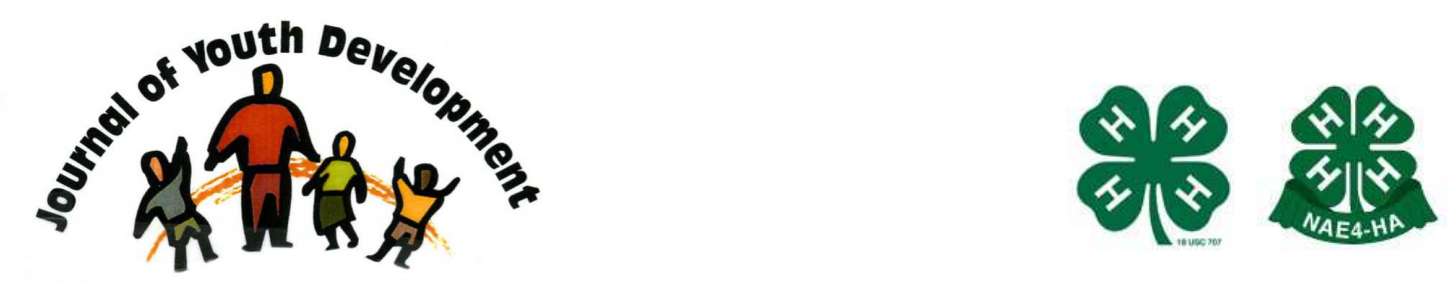

Bridging Research \& Practice

\title{
The 4-H Youth Development Professionals Workload Relationship to Job Satisfaction
}

\author{
Carrie Stark \\ 4-H Youth Development \\ University of Idaho Extension \\ Moscow, ID \\ cstark@uidaho.edu \\ Rachelle Vettern \\ Volunteer and Leadership Development \\ North Dakota State University Extension \\ rachele.vettern@ndsu.edu \\ Deb Gebeke \\ Family and Consumer Science \\ North Dakota State University Extension \\ debra.gebeke@ndsu.edu \\ Greg Lardy \\ Department of Animal Science \\ North Dakota State University \\ gregory.lardy@ndsu.edu \\ Myron A. Eighmy \\ School of Education \\ North Dakota State University \\ myron.eighmy@ndsu.edu
}




\title{
JOURNAL OF YOUTH DEVELOPMENT \\ bridging research and practice

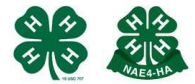

Volume 7, Number 3, Fall 2012

Article 120703FA002

\section{The 4-H Youth Development Professionals Workload Relationship to Job Satisfaction}

\author{
Carrie Stark \\ University of Idaho Extension \\ Rachelle Vettern, Deb Gebeke, Greg Lardy and Myron A. Eighmy \\ North Dakota State University
}

\begin{abstract}
A study to determine what job responsibilities Extension 4-H youth development professionals $(n=241)$ chose to spend their work time doing and how the workload related to their job satisfaction and burnout is discussed in this paper. Workload was determined using the 4-H Professional, Research, Knowledge, and Competencies (4-H PRKC). Professionals identified their level of job satisfaction and burnout. Based on the previous research on workload, burnout, and job satisfaction, 4-H youth development professionals are prime candidates for experiencing low job satisfaction and increased burnout, which may lead to professionals leaving the organization early. $4-\mathrm{H}$ youth development professionals reported being satisfied with their job and felt very little burnout. Even with the positive job satisfaction and low burnout, there are strategies shared for each of the 4-H PRKC domains to help 4-H professionals continue to have a high level of job satisfaction and low burnout. Many of the strategies that are shared in this paper are applicable to not only $4-\mathrm{H}$ youth development professionals but to any professional who works in the field of youth development.
\end{abstract}

\section{Introduction}

Research and teaching are the missions of most of America's public colleges and universities, but for more than 100 land-grant colleges and universities, there is the third mission of outreach or Extension (U.S. Department of Agriculture [USDA], 2010). Information disseminated by Extension is intended to solve community problems or promote change within a community or individuals (USDA, 2010). 
According to the UDSA (2011), the number of U.S. farms is slightly increasing, but the demographics of those farms are changing. The size of the farms will become smaller, both in size and number of crops grown. These changes with traditional agriculture will affect the Extension system in several ways. The audience whom Extension serves will become more diverse. According to USDA (2010), Extension will continue to meet the needs of the public at the local level but in a different way.

The second way Extension will be affected is in the recruitment and retention of county Extension professionals. Borr and Young (2010) report that $74 \%$ of the Extension professionals in North Dakota plan on leaving their current positions within the next 10 years, and fewer than $15 \%$ plan on moving into another position within Extension. According to the National Institute of Food and Agriculture (NIFA, 2008), the average number of service years for field staff (county Extension professionals) is 19 years, meaning that, in 10-15 years, there will be more retirements and a need for new employees. With the elevated attrition rate, many of the vacant positions could remain unfilled, thus increasing the remaining employees' workload and stress levels (Borr \& Young, 2010).

The funding for Cooperative Extension comes from federal, state, and local funds. The economic declines have forced many state Cooperative Extension Systems to defend their budgets. Fischer (2009) identified seven state Extension programs (Ohio, Michigan, Iowa, Minnesota, Louisiana, Idaho, and Oregon) which are making big changes. Iowa State University Extension eliminated the 100 county-based districts and opened 20 regional centers, eliminating the county and area director positions. Michigan State University Extension has eliminated 82 county Extension director positions and hired 13 district coordinators who each oversee 5 to 10 counties. In addition to the states that have been affected by severe budget cuts, 39 states had a decrease in higher education budgets for fiscal year 2010 (Johnson, Oliff, \& Williams, 2010).

\section{Background to the Study}

\section{Staffing Trends and Shifts}

In the summer of 2006, a survey was conducted to determine the structure of the 4-H profession. Questions were asked regarding staffing structure, staffing trends and changes, ideal staffing models, and challenges to 4-H staffing (Astroth, 2007). Based on responses from all 50 states, Astroth (2007) was able explain the significant changes to the staffing structure of $4-\mathrm{H}$ youth development in the past 20 years.

Astroth (2007) found that $58 \%$ of the state $4-\mathrm{H}$ program leaders reported the number of state staff FTEs funded with appropriated dollars had decreased since 1990 while $28 \%$ of the states reported that their state staff FTEs had increased. Furthermore, $9 \%$ of the state $4-\mathrm{H}$ program leaders responded that their state staff was the same size as it was in 1990, and $4 \%$ of the state 4-H program leaders did not know if their state staff had increased or decreased.

The county staffing-level changes were similar to the state levels. Forty-eight percent of the states reported a decrease in the number of FTEs working with county $4-\mathrm{H}$ programming, and $28 \%$ had seen an increase in $4-H$ FTEs since 1990 . There were $15 \%$ who reported no change and $9 \%$ who did not know. The percentage of states that reported a decrease increased to $54 \%$ when the total number of people was counted, rather than the number of FTEs.

At the county level, $56 \%$ of the states described an increase in paraprofessional positions. There were $13 \%$ of the state $4-\mathrm{H}$ program leaders who reported a decrease in this type of staff, 
and $13 \%$ of the states did not see any change in these numbers. Seventeen percent of the states did not know if there was a change in this type of staffing. One state 4-H program leader reported, "Because of decreased state and federal funding, we have replaced many former $100 \%$ 4-H agent positions with program assistants" (Astroth, 2007, para. 42).

\section{Workload and 4-H PRKC}

According to Harder and Dooley (2007), there was a need to make sure the 4-H youth development professionals were well-prepared to handle the demands of their jobs. Based on the need, a group of 4-H professionals identified a base of $4-\mathrm{H}$ knowledge and research. This knowledge and research base was created to help guide the 4-H professional's efforts in working with and on behalf of youth. In 1985, the knowledge base became known as the 4-H Professional, Research, and Knowledge. The 4-H PRK developed a set of competencies that reflected the true nature of 4-H youth development work (Harder \& Dooley, 2007).

As indicated by Stone and Rennekamp (2004), the research and knowledge base was updated in 2004 to include competencies essential for conducting 4-H youth development programs to create the 4-H Professional Research, Knowledge, and Competencies, known as the 4-H PRKC. This framework focused on the important elements of working with young people and provided guidelines for $4-\mathrm{H}$ youth development professionals and could be easily converted into job responsibilities.

\section{Workload}

Those professionals who work in youth development are faced with challenges and opportunities on a regular basis. Astroth and Lindstrom (2008) found that one of the issues in youth development is the high rate of employee turnover. The authors found there were several reasons for this turnover. First, the financial compensation for youth workers, including those who work in 4-H youth development, is not very high. The profession tends to attract young, energetic individuals who see it as a job, not a career, and may leave within a few years for a higher-paying position. The second issue facing youth development professionals is long and irregular work hours. Working occasional evenings and weekends may disrupt a worker's personal life, leading to burnout, and is the principle reason youth workers cited for leaving the profession. The Annie E. Casey Foundation (2003) published a national report which cited burnout, extreme workloads, long hours, and high turnover as part of youth development work.

According to Kutilek, Conklin, and Gunderson (2002), a research study was commissioned by the Joint Council for Extension Professionals (JCEP) to study work/life issues for Extension professionals. The study included a random sample of employed Extension professionals from across the United States. The research participants were asked to report on work/life balance issues. Those issues identified were workload, time, control/balances, and personal attitude/expectations. The factors given as the greatest influences in the number of hours worked were one's own self, clientele, and immediate supervisors. The respondents also reported that a reduction in workload would be one way their work/life balance could be better supported.

Another study conducted at the University of Idaho by Church and Pals (1982) investigated the reasons Extension professionals leave the profession. The factors that influenced Extension professionals to stay or leave their jobs included the chance for advancement and promotion, evening and weekend work, and salary. The majority of the 4- $\mathrm{H}$ youth development professionals who left reported that the evening and weekend work was the reason they left. 


\section{Job Satisfaction}

Job satisfaction has been defined many different ways. Hoppcock (1935) defined job satisfaction as any combination of psychological, physiological, and environmental circumstances that cause workers to say they are satisfied with their job. Petty, Brewer, and Brown (2005) discussed Brayfields' definition of job satisfaction which was "a feeling or affective state that employees had towards their job" (p. 59). Spector (1985) defined job satisfaction as "an emotional affective response to a job or specific aspect of a job" (p. 695). Over the years, job satisfaction was defined both by overall job satisfaction as well as by varying factors which can affect one's job satisfaction (Petty et al., 2005).

Jewell, Beavers, Kirby, and Flowers (1990) reported that there was a relationship between turnover (or occupational change) and job satisfaction. Salary, benefits, job security, and the ability to retire are reasons individuals gave for remaining in a job (Borzaga, 2006; Long \& Swortzel, 2007). Petty et al. (2005) found that the years of service to an organization or company affected an employee's level of job satisfaction. Employees with 3-7 years of service tended to have a lower job satisfaction than other employees.

Extension professionals need to be aware of factors related to job satisfaction, including attitudes towards the organization and colleagues, and to understand that a reduction in any one factor may lead to reduced job satisfaction. Extension professionals who are unable to cope with stressful situations at work will have lower job satisfaction.

Balancing work and family is a continual struggle for Extension personnel (Fetsch \& Kennington, 1997). Extension work regularly requires long hours, including nights and weekends. Extension professionals often find themselves in conflict among the demands on their time and energy by clientele, administrators' expectations, family expectations, and family priorities. The expectation to work extra nights and weekends seems to be more prevalent with personnel who are single (Babkirk \& Davis, 1982). Fetsch and Kennington (1997) explained that, in times of uncertain funding, Extension professionals are increasingly pressured to do more with less.

\section{Methodology}

The population for this study was Extension professionals from the University of Idaho Extension, Washington State University Extension, Colorado State University Extension, Montana State University Extension, the University of Wyoming Extension, and Oregon State University Extension, all of which are 1862 land-grant universities. The potential participants were comprised of state- and county-based professionals, including Extension Educators, 4-H program coordinators, 4-H program assistants, and others (e.g., office staff who also have a 4-H appointment). Table 1 is a summary of the 4-H youth development professionals who were invited to participate from each land-grant university and the number of actual participants. 
Table 1

Potential and Actual County-Based and State-Based Participants from Six Land-Grant University Extension Programs

\begin{tabular}{lccc}
\hline $\begin{array}{l}\text { State } \\
\text { County-Based Professionals } \\
\text { Eligible to Participate }\end{array}$ & $\begin{array}{c}\text { Actual Professionals Who } \\
\text { Participated }\end{array}$ & $\begin{array}{c}\text { Actual Response Rate } \\
\text { Percentage }\end{array}$ \\
$\begin{array}{l}\text { Idaho } \\
\text { Oregon }\end{array}$ & 57 & 53 & $79.1 \%$ \\
Washington & 84 & 36 & $42.8 \%$ \\
Montana & 123 & 36 & $29.3 \%$ \\
Colorado & 74 & 43 & $58.1 \%$ \\
Wyoming & 73 & 39 & $50.7 \%$ \\
TOTAL & 27 & 15 & $55.6 \%$ \\
& $\mathbf{4 4 8}$ & $\mathbf{2 2 2}$ & $\mathbf{4 9 . 6 \%}$ \\
State-Based Professionals & & & \\
Idaho & 6 & 5 & $83.3 \%$ \\
Oregon & 14 & 7 & $50.0 \%$ \\
Washington & 16 & 5 & $31.3 \%$ \\
Montana & 7 & 5 & $71.4 \%$ \\
Colorado & 7 & 7 & $100.0 \%$ \\
Wyoming & 4 & 0 & $0.0 \%$ \\
TOTAL & $\mathbf{5 4}$ & $\mathbf{2 9}$ & $\mathbf{5 2 . 7 \%}$ \\
\hline Colorado State Univial & & \\
\hline
\end{tabular}

Colorado State University (2010); Montana State University (2010); Oregon State University (2010); University of Idaho (2010); University of Wyoming (2010); Washington State University (2010).

\section{Instrumentation}

The workload of 4-H youth development professionals was determined by evaluating their job responsibilities as established by the 4-H Professional, Research, Knowledge, and Competencies (4-H PRKC). Study participants were asked to determine what percentage of time they spend in each of the six domains as well as how much time they felt should be spent in each of the domains, as well as to determine which job responsibilities from the 4-H PRKC competencies the 4-H youth development professionals focused. The participants were asked to rank order those job responsibilities from the one on which they spend the most time to the one on which they spend the least amount of time. Ranking was completed for each of the six domains, with seven job responsibilities in each domain.

For each of the domains and competencies (job responsibilities), the study participants were asked to reflect on their level of job satisfaction, and to self-report on a Likert-type scale from 1 to 5. To further assess job satisfaction, participants completed the Job Satisfaction Survey by Spector (1985). This instrument assessed both overall job satisfaction and level of satisfaction related to pay, promotion, supervision, fringe benefits, contingent rewards (performance-based rewards), operating procedures (required rules and procedures), co-workers, nature of work, and communication. The participants were also asked to report their overall level of job satisfaction. The job satisfaction was based on a Likert-type scale of 1 to 5 with $1=$ extremely satisfied and 5 = extremely dissatisfied. 


\section{Data Analysis}

The findings of this study were reported using the mean, standard deviation, frequency percentages, analysis of variance (ANOVA) and tukey HSD (honestly significant difference), and pearson product-moment correlation coefficient.

The entire survey was pilot tested by a group of experts to analyze the workload and burnout portions for content and test validity. The expert panel was members of the 2009-2010 National Association of Extension 4-H Agents Board. The panel of experts represented all levels of the 4-H youth development field, from state to district to county staff members. A Cronbach's Alpha test was used to test reliability after completion of the study. The overall Cronbach's Alpha was 0.824 .

\section{Results}

\section{Workload}

4-H youth development professionals were asked to rank a set of job responsibilities that were related to the 4-H Professional, Research, Knowledge, and Competency (4-H PRKC) model which was designed to provide a framework for quality youth development. The respondents were asked to determine on which of the six domains they spent the greatest percentage of work time and where they thought the greatest percentage of work time should be spent. The 4-H youth development professionals reported spending $27.2 \%$ of their time working within the youth program development domain, which was also the domain where they thought the greatest percentage of time should be spent. Table 2 illustrates the average amount of work time that 4-H youth development professionals reported spending on each of the six 4-H PRKC domains and the amount of work time that should be spent within each of the same domains, based on a percentage of time.

Table 2

Self-Reported Percentage of Work Time Actually Spent and Where Work Time Should Be Spent for Each 4-H PRKC Domain Reported by Participating 4-H Youth Development Professionals $(N=205)$

\begin{tabular}{lcc}
\hline \multicolumn{1}{c}{ Domain } & $\begin{array}{c}\text { Actual Percentage of } \\
\text { Work Time Spent }\end{array}$ & $\begin{array}{c}\text { Percentage of Work } \\
\text { Time that Should Be } \\
\text { Spent }\end{array}$ \\
\hline Youth Program Development Domain & $27.2 \%$ & $24.8 \%$ \\
Youth Development Domain & $21.6 \%$ & $23.3 \%$ \\
Volunteerism Domain & $20.7 \%$ & $19.8 \%$ \\
Partnership Domain & $14.2 \%$ & $11.8 \%$ \\
Organizational Systems Domain & $9.1 \%$ & $10.7 \%$ \\
Equity, Access, and Opportunity Domain & $7.3 \%$ & $9.6 \%$ \\
\hline
\end{tabular}

When determining the ranking of the job responsibilities, each domain had seven job responsibilities that were common to the youth development profession. The 4-H youth development professionals were asked to rank order these seven tasks from the one they did the most often (score of 1 ) to the one they did the least (score of 7). The job responsibility that had the lowest mean $(M=2.26, S D=1.81)$ of any job responsibility from the six domains was \#1 "using volunteer committees" in the volunteerism domain; $71.9 \%$ of the respondents ranked the job responsibility as one of the top two. Participating in professional development opportunities related to growth and development (job responsibility \#1 within the youth 
development domain) had the greatest mean for the six domains $(M=5.40, S D=1.77)$; $57.3 \%$ of the respondents ranked this job responsibility as either a 6 or 7 .

\section{Job Satisfaction}

4-H youth development professionals were asked to determine their level of job satisfaction for each of the six 4-H PRKC domains. Table 3 shows the results for the domains self-reported jobsatisfaction levels. All six domain results indicated that $4-\mathrm{H}$ youth development professionals were satisfied.

\section{Table 3}

Descriptive Statistic Results for the Self-Reported Job Satisfaction of the 4-H PRKC Domains for Participating Youth Development Professionals

\begin{tabular}{|l|c|c|c|c|c|c|c|c|}
\hline \multirow{2}{*}{ Domain } & \multicolumn{3}{|c|}{ Job Satisfaction } & \multicolumn{5}{c|}{ Frequency Percentages } \\
\cline { 2 - 9 } & $N$ & $M$ & $S D$ & 1 & 2 & 3 & 4 & 5 \\
\hline $\begin{array}{l}\text { Youth Development } \\
\text { Domain }\end{array}$ & 202 & 2.06 & 0.86 & 25.2 & 51.5 & 14.9 & 8.4 & 0.0 \\
\hline $\begin{array}{l}\text { Youth Program } \\
\text { Development Domain }\end{array}$ & 200 & 2.11 & 0.84 & 21.0 & 56.5 & 13.0 & 9.5 & 0.0 \\
\hline Volunteerism Domain & 197 & 2.63 & 0.98 & 8.6 & 44.7 & 23.9 & 20.3 & 2.5 \\
\hline $\begin{array}{l}\text { Equity, Access, and } \\
\text { Opportunity Domain }\end{array}$ & 190 & 2.82 & 0.85 & 5.8 & 28.9 & 43.7 & 21.1 & 0.5 \\
\hline Partnership Domain & 192 & 2.60 & 0.93 & 8.9 & 42.7 & 28.6 & 18.8 & 1.0 \\
\hline $\begin{array}{l}\text { Organizational } \\
\text { Management Domain }\end{array}$ & 194 & 2.73 & 0.97 & 5.7 & 41.8 & 32.5 & 14.4 & 5.7 \\
\hline
\end{tabular}

Note: Job Satisfaction Scale: 1 = extremely satisfied; 2 = satisfied; 3 = neither dissatisfied nor satisfied; 4 = dissatisfied; and 5 = extremely dissatisfied.

Determining job satisfaction related to the individual job responsibilities was the first mode used in identifying the level of job satisfaction in the survey. The 4- $\mathrm{H}$ youth development professionals were asked to self-report their level of job satisfaction based on a Likert-type scale of 1 to 5, 1 with being extremely satisfied and 5 being extremely dissatisfied. All of the 42 job responsibilities had a mean between 1.00 and 2.99 for the study participants.

The youth development domain's job responsibility \#5 "develop programs to practice life skills" provided the respondents with the greatest degree of job satisfaction for any of the responsibilities within the six 4-H PRKC domains. The mean for responsibility \#5 was 1.93 (SD $=0.72) ; 85.8 \%$ of the respondents reported either an extremely satisfied or satisfied level of job satisfaction.

The second method of determining the level of job satisfaction was the Job Satisfaction Survey (JSS). The overall mean for the JSS was $3.72(S D=0.79)$. The lowest level of job satisfaction of the nine facets was the pay facet $(M=2.71, S D=0.68)$. The greatest job satisfaction $(M=4.93, S D=0.18)$ was within the nature of the work itself.

All respondents were asked to report their overall level of satisfaction which was 2.20 $(S D=0.83) ; 79.2 \%$ of the group reported being either extremely satisfied or satisfied with their current job. 


\section{Workload and Job Satisfaction}

To determine if a relationship existed between the different job satisfaction variables (rank order of job responsibility, job satisfaction of individual job responsibilities, level of job satisfaction for the 4-H PRKC domain, overall JSS score, and overall self-reported job satisfaction.) and the workload of 4-H professionals, a Pearson-product moment correlation coefficient was conducted. Job responsibility \#2 "creating positive relationships" had the strongest positive relationship $(r=.505, p<.05)$ between workload and job satisfaction. This relationship was between the degree of reported job satisfaction for the job responsibility and the rank score for the job responsibility.

\section{Conclusions}

\section{Workload}

The 4-H youth development professionals from the six western land-grant university Extension systems who participated in this study gave a greater rank score to tasks that allowed them to work directly with people and a lower rank score on tasks related to infrastructure or office-type job responsibilities. Even though each domain was independent of the others, there were some job responsibilities with a higher response frequency when ranking as the top one or two or as the bottom choice (a rank of a seven).

The job responsibility that was ranked on top within the volunteerism domain (using volunteer committees) also had the greatest percentage of being ranked as the top response for any of the 4-H PRKC domains. This job-related task had $52.5 \%$ of the respondents ranking it as the one they performed most. It is important that 4-H youth development professionals have the skills or knowledge to facilitate groups. Working with groups or committees requires good facilitation skills. Organizations should hire individuals who already have those skills or offer additional professional development in order to assure their $4-\mathrm{H}$ professionals have the skills needed.

The 4-H youth development professionals reported spending $20.7 \%$ of their work time completing job-related tasks in the volunteerism domain. Understanding and utilizing a volunteer middle-management program for the local 4-H program would alleviate some of the workload usually done by the 4-H youth development professional. An example of a job responsibility that could be turned over to a volunteer middle manager would be recruiting volunteers. This job responsibility was ranked $7^{\text {th }}$ (out of 7 ) for the amount of time 4-H youth development professionals spent on it. A 4-H youth development program may not be feasible if there is a lack of volunteers to lead the youth. Understanding how to work with volunteers is a knowledge-base needed by $4-\mathrm{H}$ professionals, and these skills could be increased for the current professionals through added professional development opportunities.

In the equity, access, and opportunity domain, $40.4 \%$ of the $4-\mathrm{H}$ youth development professionals reported spending the least amount of time on designing materials for diverse audiences. Depending on where the 4-H youth development professional lives and works, there may not be a great demand to design materials for diverse audiences. This domain may also require additional diversity training that goes beyond ethnic diversity. When professionals understand all definitions of diversity, it may lead them to spend more time in the equity, access, and opportunity domain. For those 4-H youth development professionals who live in geographic areas that do have diverse audiences, providing the resources needed to reach 
those audiences, including 4-H publications in the audience's native language or specialized training on issues around diversity, would be appropriate.

\section{Job Satisfaction}

As a group, 4-H youth development professionals were satisfied with their work within all six domains. The greatest job satisfaction was within the youth development and the youth program development domains. These domains were also ranked the highest as far as the percentage of work time. The correlation between the percentage of spent time and the level of job satisfaction revealed a weak, negative relationship (between 0.300 and 0.100 ) for both domains. This conclusion indicates that, as the percentage of time spent working within these domains increases, the level of job satisfaction should decrease. This finding also suggests that 4-H youth development professionals should monitor the amount of time they spend doing work in any one domain. Spending time in a variety of activities within each of the six 4-H PRKC domains may help the 4-H youth development professionals' level of job satisfaction increase rather than decrease.

A positive, moderate relationship (between 0.500 and 0.300 ) was reported between the 4-H youth development professionals' self-reported level of satisfaction for the youth development domain and their self-reported overall job satisfaction. A positive, moderate relationship was also found for the youth program development domain. A weak, positive relationship was found between the self-reported level of job satisfaction for the volunteerism and partnership domains and the self-reported level of overall job satisfaction. For all of these domains, the data revealed that, as the 4-H youth development professionals' level of job satisfaction increases for work related specifically to the youth development and youth program development domains, their overall job satisfaction should also increase.

The results of the workload portion of this study indicated that 4- $\mathrm{H}$ youth development professionals spent the majority of their time on job responsibilities that allowed them to work directly with people (e.g., develop programs for youth to practice life skills; provide opportunities for youth to explore skills in project areas; create positive relationships with members, parents, leaders, and the community; and create programs for youth). The same job responsibilities had the greatest reported levels of job satisfaction for 4-H youth development professionals in the youth development domain.

The 4-H youth development professionals were generally satisfied with their job, which could be partially due to the fact that they worked with people, especially youth, on a regular basis. When those opportunities are taken away and 4-H youth development professionals have to work on other job responsibilities, such as dealing with conflict management issues, the professionals' level of job satisfaction may go down. Finding a way to successfully help 4-H youth development professionals positively manage conflict situations may help increase the professionals' level of job satisfaction for both the individual job responsibility and the youth development domain. A possible solution could be to provide training in basic mediation skills for 4-H youth development professionals so that they are better equipped with the skills needed to handle conflict.

According to the literature (Borzaga, 2006; Petty et al., 2005), professionals in the human development field have a greater level of job satisfaction than professionals in similar fields. The results for the overall JSS score for this study indicated that 4- $\mathrm{H}$ youth development professionals were slightly satisfied with their jobs $(M=3.72)$, which supports the previous literature findings. 
The 4-H youth development professionals reported satisfaction with all 42 job responsibilities (seven job responsibilities in each of the six domains) related to the 4-H PRKC. This result, together with the JSS score, indicated that 4-H youth development professionals are satisfied with their jobs.

The 4-H youth development professionals were slightly dissatisfied with the statements in the contingent rewards facet. There are simple ways to improve job satisfaction and to reward professionals for their work without costing the organization any money. For example, the organization could recognize a 4-H youth development professional who has done an exceptional job in a newsletter or with a handwritten note.

\section{Recommendations to Educators and Practitioners}

This study had a number of implications for both 4-H youth development professionals and the individuals who supervise them. The literature review indicated a relationship between job satisfaction to employee turnover (Rousan \& Henderson, 1996; Safrit et al., 2009; Strong \& Harder, 2009). The present study provided additional evidence that 4-H youth development professionals are generally satisfied with their job.

The first recommendation derived from the results of this study was that position descriptions should accurately reflect the work of 4-H youth development professionals and that performance evaluations should be based on the position description. The administration needs to recognize the differences between the responsibilities of 4- $\mathrm{H}$ youth development professionals and other Extension professionals. To determine the differences, the administration should evaluate the current position descriptions used by both 4-H youth development and other Extension professionals. Understanding the programming trends for the 4- $\mathrm{H}$ youth development profession is vital to comprehend what type of job responsibilities are required for $4-\mathrm{H}$ youth development professionals. An example is the current attention to science, engineering, and technology (SET) programs, which is a mission mandate of 4-H National Headquarters. It is expected that each state will conduct SET programming. Extension administration should support programming areas which move the organization forward.

Many youth development professionals often work beyond the normal 40-hour work week, which was reflected in this study when 4-H youth development professionals reported they were dissatisfied with the amount of work currently expected of them. It is important for the supervisors of any youth development professional understand the type of work and the amount of time involved during weekend and evening meetings or programs. If the current policies of the organization do not support the needs of the professional, a policy should be researched to determine how the youth development professional will be compensated for the extra hours. For Extension, these policies should be in place for all employees, not just 4-H youth development professionals.

Flexible hours or formal compensation are two options to consider. Supervisors need to be supportive of the professionals' personal needs. The 4-H youth development professionals may have worked nights or weekends, so they may need to take time off during the normal work week to do personal errands. It could also be as simple as not expecting an Extension professional to be in the office as soon as it opens if there were a meeting the night before. This arrangement needs to be agreed upon at the beginning of an Extension professional's career and should be communicated with colleagues in the office. 
The results of this study indicated that 4-H youth development professionals prefer to work with others. Working with others allows the workload to be distributed among the team members, decreasing the workload of $4-\mathrm{H}$ professionals. For example, a team of $4-\mathrm{H}$ youth development professionals located in close physical proximity could be divided by programming interests. The 4-H professional with a stronger background in meat animal projects could take the lead for that programming area in the geographic region. Another person could take the lead for science, engineering, and technology (SET) programming. This method of workload distribution may require changes to state or county policy regarding how the workload is dispersed and the travel boundaries. Extension administration may need to evaluate current policies to determine if this model is feasible or how it could be accomplished. This change may take a combination of administration and 4-H youth development team members to develop a plan to make the team concept work. The administration may need to approach stakeholders to explain the plan and benefits to the county.

The 4-H youth development professionals disagreed with the statements related to organizational communication that were in the communications facet of the Job Satisfaction Survey. Based on the disagreement with these statements, 4-H youth development professionals do not feel that the organization communicates effectively with them, especially during times of severe budget cuts. The 4-H youth development professionals who completed this study reported that knowing the direction of the organization was important. The 4-H youth development professionals also value effective communication from administration regarding organizational goals. This finding suggests that a core need to seek input from all 4-H youth development professionals regarding the organization's direction is critical. It is suggested that the administration should gather input from professionals who are directly affected by changes during the decision-making process. Depending on the land-grant university, county program assistants and county program coordinators who are paid through county funds are not always invited to participate in university-sponsored professional development or planning opportunities. Everyone on the 4-H youth development team should be invited to participate in the professional development opportunities and planning sessions in order to share their expertise as front-line professionals.

The final recommendation is to conduct exit interviews with the 4- $\mathrm{H}$ youth development professionals who leave the organization before retirement to determine why they leave. There should be a set of pre-determined questions to help identify if any of the factors identified in this study had an effect on an individual's decision to leave the organization.

\section{References}

Annie E. Casey Foundation. (2003). The unsolved challenge of system reform: The condition of the frontline human services workforce. Retrieved from http://www.aecf.org/upload/publicationfiles/the\%20unsolved\%20challenge.pdf

Astroth, K.A. (2007, Fall). Making the best better: 4-H staffing patterns and trends in the largest professional network in the nation. Journal of Youth Development: Bridging Research and Practice, 2(2). Retrieved from http://data.memberclicks.com/site/nae4a/JYD 070202final.pdf

Astroth, K.A., \& Lindstrom, J. (2008). Investing in professional development: Building and sustaining a viable 4-H youth workforce for the future. Journal of Youth Development, 3(2). Retrieved from http://data.memberclicks.com/site/nae4a/JYD 080302final.pdf 
Babkirk, D.G., \& Davis, N.R. (1982). The incredible balancing act. Journal of Extension, 20(5), 5-6.

Borr, M.L., \& Young, R.B. (2010). Retirement and attrition trends in Extension professionals in North Dakota. Journal of Extension, 48(1). Retrieved from

http://www.joe.org/joe/2010february/rb4.php

Borzaga, C. (2006). Worker motivations, job satisfaction, and loyalty in public and nonprofit social services. Nonprofit \& Voluntary Sector Quarterly, 35(2), 225-248.

Colorado State University. (2010). Personnel Directory. Retrieved from www.ext.colostate.edu/cdirectory/

Church, L.J., \& Pals, D.A. (1982). Before you resign. Journal of Extension, 20(5), 43-49.

Fetsch, R.J., \& Kennington, M.S. (1997). Balancing work and family in Cooperative Extension: History, effective programs, and future directions. Journal of Extension, 35(1). Retrieved from http://www.joe.org/jor/1997february/a2.html

Fischer, K. (2009, December 13). Economy forces land-grant universities to reshape Extension work. The Chronicle of Higher Education. Retrieved from http://chronicle.com/article/EconomyForces-Land-Grant/49456

Harder, A., \& Dooley, K.E. (2007). Perceptions of important competencies for early-career and established 4-H agents. Journal of Southern Agricultural Education Research, 571), 43-52.

Hoppcock, R.H. (1935). Job satisfaction. New York, NY: Harper \& Brothers.

Jewell, L.R., Beavers, K.C., Kirby, B.J., \& Flowers, J.L. (1990). Relationships between levels of job satisfaction expressed by North Carolina vocational agriculture teachers and their perceptions towards the agricultural education teaching profession. Journal of Agricultural Education, 31(1), 52-57.

Johnson, N., Oliff, P., \& Williams, E. (2010). Center on budget and policy priorities update on state budget cuts. Retrieved from http://www.cbpp.org/cms/index.cfm?fa $+=$ view\&id=1214

Kutilek, L.M., Conklin, N.L., \& Gunderson, G. (2002). Investing in the future: Addressing work/life issues of employees. Journal of Extension, $40(1)$. Retrieved from http://www.joe.org/joe/2002february/a6.php

Long, J.L., \& Swortzel, K.A. (2007). Factors influencing job satisfaction of Extension agents in the Mississippi State University Extension Service. Proceedings of the American Association for Agricultural Education Research Conference, Minneapolis, MN, 34,41-53.

Montana State University. (2010). Montana State University Extension Field Office Directory. Retrieved from http://msuextension.org/directory.

National Institute of Food and Agriculture. (2008). Salary analyses of Cooperative Extension Service positions report. Retrieved from www.csrees.usda.gov/about/human res/pdfs/report2008.pdf 
Oregon State University. (2010). County office location directory. Retrieved from http://extension.oregonstate.edu/locations.php

Petty, G.C., Brewer, E.W., \& Brown, B. (2005). Job satisfaction among employees of a youth development organization. Child \& Youth Care Forum, 34(1), 57-73.

Rousan, L.M., \& Henderson, J.L. (1996). Agent turnover in Ohio State University Extension. Journal of Agricultural Education, 372), 7-15.

Safrit, R.D., Gliem, R.R., Gliem, J.A., Owen, M., \& Sykes, W. (2009). A quantitative study of retention of North Carolina Cooperative Extension county program professionals. Proceedings of the American Association for Agricultural Education Research Conference, Louisville, KY. Retrieved from http://www.aaaeonline.org/files/national 09/papers/14.pdf

Spector, P.E. (1985). Measurement of human service staff satisfaction: Development of the Job Satisfaction Survey. American Journal of Community Psychology, 13, 693-713.

Stone, B., \& Rennekamp, R. (2004). New foundations for the 4-H youth development profession: 4-H professional research, knowledge, and competencies study, 2004. Conducted in cooperation with the National 4-H Professional Development Task Force. 4-H National Headquarters, National Institute of Food and Agriculture, United States Department of Agriculture. Retrieved from http://www.national4-hheadquarters.gov/library/4Hprkc study 010605.pdf

Strong, R., \& Harder, A. (2009). Implications on maintenance and motivation factors on Extension agent turnover. Journal of Extension, $4 \pi 1$ ). Retrieved from http://www.joe.org/joe/2009february/a2.php

United States Department of Agriculture. (2010). About us. Retrieved from http://www.csrees.usda.gov/qlinks/extension.html

United States Department of Agriculture. (2011). 2007 census of agriculture - farm numbers [Fact Sheet]. Retrieved from http://www.agcensus.usda.gov/Publications/2007/Online Highlights/Fact Sheets/farm number $\underline{\text { s.pdf }}$

University of Idaho. (2010). Extension personnel directory. Retrieved from http://www.extension.uidaho.edu/admin/personnel.asp

University of Wyoming. (2010). Area/county/state offices. Retrieved from www.uwyo.edu/ces/areas/index.html.

Washington State University. (2010). Washington State 4-H program staff directory. Retrieved from http://4h.wsu.edu/staffdir/counties.html

(C) Copyright of Journal of Youth Development $\sim$ Bridging Research and Practice. Content may not be copied or emailed to multiple sites or posted to a listserv without copyright holder's express written permission. However, users may print, download or email articles for individual use. 